\title{
ANTÍGONA Y ELECTRA RESTITUIDAS: VOCES MÍTICAS FEMENINAS EN LA ESCRITURA DE DOS AUTORAS DEL MUNDO HISPANO
}

\author{
ANTIGON AND ELECTRA RESTITUTED: \\ FEMALE MYTHICAL VOICES IN THE WRITING OF TWO \\ AUTHORS FROM THE HISPANIC WORLD
}

\author{
Ester Abreu Vieira de Oliveira' \\ [https://orcid.org/0000-0001-9959-1418] \\ Solveig Josefina Villegas Zerlin ${ }^{2}$ \\ [https://orcid.org/0000-0001-7824-6316] \\ DOI:10.30612/raido.v15i38.14785
}

RESUMO: En el presente artículo, emprendemos una lectura crítica de las piezas literarias La tumba de Antígona (1967), de María Zambrano (España), y Otra Electra (2011), de Edith Ibarra (México), por cuanto consideramos que las mencionadas autoras reelaboran los mitos de dichas mujeres de la antigüedad restituyendo sus voces y, con ello, abriendo las posibilidades de un diálogo estético renovado desde la aproximación filosófica y la psicológica, respectivamente. Las propuestas de Carlos García Gual (2003), Ester Abreu Vieira de Oliveira y Maria Mirtis Caser (2019) y Daniel Rinaldi (2000) integran el entramado teórico con el cual sustentamos nuestro abordaje. La perspectiva encarnada en las reelaboraciones de Zambrano e Ibarra, develan las voces femeninas en la plenitud del cuestionamiento de los elementos opresores de la sociedad patriarcal; a su vez, la búsqueda del sentido de lo humano cifrada en las visiones epocales de sus producciones estéticas.

Palavras-chave: Literatura en lengua española; María Zambrano; Edith Ibarra; Antígona; Electra.

ABSTRACT: In this article, we undertake a critical reading of the literary pieces La tumba de Antígona (1967), by María Zambrano (Spain), and Otra Electra (2011), by Edith Ibarra (Mexico), since we consider that the aforementioned authors rework the myths of these women of antiquity restoring their voices and, with it, opening the possibilities of a renewed aesthetic dialogue from the philosophical and psychological approaches, respectively. The proposals of Carlos García Gual (2003), Ester Abreu Vieira de Oliveira and Maria Mirtis Caser (2019) and Daniel Rinaldi (2000) integrate the theoretical framework with which we support our approach. The perspective

\footnotetext{
1 Universidade Federal do Espírito Santo (UFES).

2 Universidade Federal do Espírito Santo (UFES).
} 
embodied in the reworkings of Zambrano and Ibarra, reveal the female voices in the fullness of the questioning of the oppressive elements of patriarchal society and, in turn, the search for the meaning of the human encrypted in the epochal visions of their aesthetic productions.

Keywords: Literature in the Spanish language; Maria Zambrano; Edith Ibarra; Antigona; Electra.

\section{INTRODUCCIÓN}

Sófocles, resulta, sin duda, uno de los poetas más famosos en reelaborar los mitos griegos de Antígona y Electra. Durante el siglo V a.C. vieron la luz las puestas en escena de sus tragedias, a partir de las cuales, echaron a andar hasta nuestros días, numerosas interpretaciones históricas, psicológicas, sociológicas, filosóficas y literarias según los diversos autores y autoras tomaron los mitos de dichas jóvenes como tema para sus obras. En el presente artículo, emprendemos una lectura crítica de las piezas literarias La tumba de Antígona (1967), de María Zambrano (España), y Otra Electra (2011), de Edith Ibarra (México), por cuanto consideramos que las mencionadas autoras logran, de diversas formas, traer a ambas mujeres de la antigüedad restituyendo sus voces y, con ello, abriendo las posibilidades de un diálogo estético inusitado y renovado desde la aproximación filosófica y la psicológica, respectivamente. Para acometer las tragedias sofocleanas hemos tomado en cuenta las ediciones del traductor y crítico español Jesús Federico Polo Arredondo, con quien, desde el ámbito de la fortuna crítica de las obras clásicas, emprendimos el abordaje de las magnas piezas del autor griego.

En la línea de lo propuesto por Rinaldi (2000), comprendemos aquí que las "versiones propias" cuyo punto de partida son los textos clásicos, suponen la emergencia de numerosas lecturas y, en correspondencia con ello, amplias posibilidades de escritura y reescritura. En tal sentido, la lectura de los textos de Zambrano e Ibarra remite al conferimiento de nuevas cargas significativas en sus jóvenes protagonistas, mujeres prefiguradas ahora desde la escritura de mujeres, cuyas voces lejos de extinguirse en los finales sombríos de las antiguas tragedias, resuenan alto y claro en la búsqueda del sentido de la vida.

Ambos personajes provienen, empero, del "ámbito de resonancia", para emplear una expresión del mitógrafo Carlos García Gual, de una antiquísima mitología, cultura y época. En este trabajo, hemos querido enmarcar como referentes, por razones de método y espacio, exclusivamente, las tragedias Antígona y Electra de Sófocles. Sin embargo, no debemos olvidar que, aun estando entre las más antiguas obras sobre estos dos personajes, al componerlas, incluso el gran Sófocles fue un reelaborador y que los mitos de ambas jóvenes se ubican mucho antes, allende el océano del tiempo y la tradición.

Sobre las reelaboraciones míticas del presente, en cuanto a la figura de Antígona, ampliable ello, a nuestro juicio, a las que se centran en Electra, Fedra, Penélope, entre muchas otras, Ester Abreu Vieira de Oliveira y María Mirtis Caser, advierten: "La retomada del mito por autore(a)s de la contemporaneidad, en especial de los escritos feministas, se debe a que en él se encuentran posibilidades de resistencia femenina al poder del patriarcalismo representante del Estado" (OLIVEIRA; CASER, 2019, p. 5). 
Y es precisamente esto último lo que ha motivado nuestra selección de estas piezas literarias, pues consideramos que aun habiendo sido llevadas a cabo y publicadas en momentos históricos diferentes y en diálogo con sociedades también diferentes, albergan en común la intención y posibilidad de explorar la experiencia vital desde la redimensión de los mitos encarnados en mujeres por parte de dos autoras de la contemporaneidad hispanoamericana.

Carlos García Gual, en el prólogo de su Diccionario de mitos, insiste a las y los lectores interesados, en la necesidad de pensar y situar, tanto como sea posible, el abordaje de las figuras míticas en su respectivo entramado mitológico, tal que se corresponde con un decurso histórico y cultural, habida cuenta de que "un mito auténtico, está enraizado en una mitología, esa red de relatos tradicionales que viven en el imaginario colectivo de un pueblo y una época" (GARCÍA GUAL, 2003, p. ix-x). El autor enfatiza que las interpretaciones míticas se suceden, numerosas, en el panorama artístico; los enclaves de las imágenes de mujeres y hombres míticos con diversos contextos y épocas resultan formidables y concomitantes con su plasticidad.

El planteamiento del gran intelectual mallorquín sobre la autenticidad de un mito, su asunción indispensable desde la puesta en relación del "imaginario colectivo" y los "relatos tradicionales" nos remite a la fundamentación teórica de Carl Jung, a propósito de los "tipos arcaicos" o arquetipos, fijados en el inconsciente colectivo de las sociedades humanas: "no concernente aos conteúdos do inconsciente coletivo, estamos tratando de tipos arcaicos -ou melhor- primordiais, isto é, de imagens universais que existiram desde os tempos mais remotos" (JUNG, 2000. p.16). Los arquetipos, comprendidos en los mitos y sus incesantes recreaciones, época tras época, en nuestras sociedades, allí, al interior de sus manifestaciones culturales y artísticas, resultan un hecho fascinante.

De este modo, las piezas literarias de María Zambrano y Edith Ibarra son tributarias de dicha circunstancia, entre el vasto número de recreaciones míticas de autoras y autores precedentes y futuros. A propósito de la comprensión del mito, Zoila Amaya, intelectual e investigadora venezolana, apunta

mitólogos y antropólogos comparten la idea de una explicación antropológica de los mitos como eventos cronológicamente acontecidos que se han ido deformando a través de la narración literaria u oral. Para los psicoanalistas, en cambio, especialmente los de la rama junguiana, los mitos constituyen la representación de imágenes arquetipalesimpresas en elinconsciente colectivo(AMAYA,2014,p.96-97)

La reflexión de esta autora, llevada a cabo desde el campo de los estudios culturales, nos anima aún más a pensar en La tumba de Antígona y Otra Electra, piezas estéticas que reelaboran los mitos de las jóvenes griegas protagonistas, desarrollando sus voces y guardando interesantes similitudes y contrastes. Por una parte, ambas son muestras de escritura femenina, substancialmente cuestionadora y crítica, situadas en el marco del mundo hispano. Por otra parte, el decurso literario elegido por María Zambrano confecciona el mito de su versión desde lo filosófico, mientras que Edith Ibarra elabora el suyo a partir de la confrontación psicológica.

Con el anhelo de profundizar en los planteamientos anteriores, este artículo se organiza en cuatro apartados. El primero, se ocupa de esbozar algunas ideas sobre 
los elementos intertextuales que, en tanto relaciones, son guardados entre las obras de Zambrano e Ibarra con las tragedias sofocleanas. En el segundo y el tercer apartado, presentamos nuestra lectura crítica sobre La tumba de Antígona y Otra Electra, interpretaciones míticas contemporáneas. El cuarto y último apartado contiene las consideraciones de cierre y un intento por justificar el título elegido para este trabajo.

\section{DE LAS MARCAS INTERTEXTUALES AL DISTANCIAMIENTO}

La tumba de Antígona (1967) y Otra Electra (2011) no son las primeras piezas escritas reelaborando los mitos de esas jóvenes griegas. Las recreaciones, como es bien sabido, han sido numerosas en cuenta de que las atribuidas a Sófocles, Eurípides y Esquilo, son, a menudo, consideradas como las principales y distinguidas en tanto clásicos. Antígona y Electra, bien como protagonistas, bien como personajes secundarios, intervienen en una o varias de las tragedias de los poetas griegos mencionados.

Así pues, a la vista de lo planteado por Gérard Genette, para quien la trantextualidad constituye: "todo lo que pone al texto en relación, manifiesta o secreta, con otros textos" (GENETTE, 1989 p.10), consideramos que las piezas literarias de María Zambrano y Edith Ibarra, dialogan de diversas formas con las tragedias antecesoras, digamos, principales, pertenecientes a Sófocles, en las cuales nos centraremos dada la demandante cortedad del presente artículo. Siguiendo la perspectiva teórica del crítico francés, estimamos que la correspondencia se establece, en ambas obras con aquéllas, desde la hipertextualidad, pues guardan relación implícita y estrecha, centrándose en las recreaciones de sus protagonistas y el devenir de sus vidas, con lo cual, los nexos con los personajes femeninos de hace veinticinco siglos, resultan indesligables.

Elemento a destacar es, junto con las protagonistas, la aparición de alguno o varios de los personajes en las piezas de nuestras escritoras, dando lugar a la aproximación de sus identidades y/o la puesta en relación en la obra en claro vínculo con las piezas clásicas.

Aseveramos pues que la correspondencia hipertextual, sitúa los trabajos de Zambrano e Ibarra como hipertextos de las tragedias sofocleanas, y entendidas éstas últimas como elaboraciones precedentes o hipotextos, que, a su vez, también han abrevado en la tradición mítica. Ello, en cuenta de lo propuesto por Genette: "toda relación que une un texto B (que llamaré hipertexto) a un texto anterior A (al que llamaré hipotexto) en el que se injerta de una manera que no es la del comentario" (GENETTE, 1989, p. 14).

Asimismo, continuando con las categorías dispuestas por el gran narratólogo francés, hallamos que existe relación de paratextualidad entablada entre las piezas de nuestras autoras y las tragedias de Sófocles, resaltando según nuestro modo de ver, al menos, dos elementos. El primero y más obvio, es la coincidencia del nombre de cada protagonista en el título; el segundo elemento, es la estructuración de ambos textos en piezas dramatúrgicas, en las cuales se sitúa a las y los lectores ante los personajes en un espacio/tiempo dado, produciéndose intercaladamente el turno de habla durante el desarrollo de la trama.

Podríamos continuar señalando una larga lista de vinculaciones intertextuales; sin embargo, nuestro mayor interés es reflexionar sobre las propuestas estéticas que 
María Zambrano y Edith Ibarra han entregado al público a través de sus piezas y cuyo tratamiento del tema supone, en ambos casos, el distanciamiento, la redimensión, las interpretaciones otras, desde las cuales las voces de Antígona y Electra han tenido una nueva oportunidad de diálogo, puesto que sin duda: "no hay que buscar la originalidad en la materia, ofrecida por la tradición (más allá de la incorporación de otras "historias"), sino en su tratamiento, en su compleja y trabajada transformación poética" (RINALDI, 2008, p.318).

\section{ANTÍGONA O EL RESPLANDOR DE LA COMPRENSIÓN}

Recordemos que, en el mito reelaborado por Sófocles en su tragedia, Antígona, ésta es hija de Edipo y de Yocasta. Tiene una hermana: Ismene y dos hermanos: Eteocles y Polínices. Su prometido se llama Hemón, y es hijo de su tío materno Creón, rey de Tebas, y de Eurídice. Lo cierto es que Eteocles y Polínices hambrientos de poder y gloria deseaban gobernar; sin embargo, se enfrentan en bandos contrarios durante el asedio a Tebas y mueren uno en manos del otro. Eteocles, quien había luchado en favor de Tebas es enterrado con honores, mas, el cuerpo de Polinices, quien peleaba en contra de la ciudad, dada a su considerable traición, es dejado para que lo devoren las bestias, por órdenes del juez y rey Creón.

Esto último, la ausencia de sepelio y la corrupción del cuerpo de esta manera, suponía para la cultura griega, la imposibilidad de que el espíritu de Polínices alcanzara el Hades y, en cambio, vagara eternamente. Ante el dolor de la pérdida de sus hermanos y el horror de que el espíritu de Polínices no hallara descanso, Antígona se rebela al dictamen de la ley humana y procede a realizar los ritos correspondientes y dar sepultura al cuerpo de Polínices. Por causa de sus deliberados actos de desobediencia y desacato a la autoridad real, Antígona es víctima de la ira y la soberbia de Creón y de la sociedad y es condenada a ingresar viva en una tumba, dentro de la cual se quita la vida. Posteriormente, Hemón desesperado intenta dar muerte a su padre sin conseguirlo, acude entonces a la tumba de su prometida y, al hallarla muerta, se suicida; así lo hace también su madre Eurídice, al saberlo muerto. Al final, Creón es presa del dolor y de un arrepentimiento tardío.

Ahora bien, en La tumba de Antígona, la protagonista es perseguida por su mundo social, literalmente, hasta su tumba. La encontramos pues, no muerta sino "despierta"; allí la buscan y la visitan las entidades familiares, tutelares e increpadoras de la misma sociedad tebana que la condenó para conminarla ahora a que regrese a vivir "bajo el Sol". Ignoran que esta Antígona ya no es la misma: su consciencia se ha abierto y sus ojos ya no van tras la luz del Sol del reino, sino tras otra luz, la de su conciencia abierta a la búsqueda de la verdad. En esta versión del mito por parte de la autora española, las circunstancias, lejos de abatirse contra la protagonista hasta destruirla, nos presentan una joven mujer que sortea su destino y alcanza la comprensión de la condición humana, en virtud de que

La Antígona de Zambrano cuestiona el papel pasivo destinado a la mujer por el poder masculino, cual sea, el estar siempre al servicio del otro, tener la existencia pensada prioritariamente para hacer más llevadera y cómoda la vida de aquellos que la rodean, en especial los miembros masculinos. (ABREU y CASER, 2019, p. 10) 
La pieza zambraniana tiene doce partes, a saber: Antígona, La noche, Sueño de la hermana, Edipo, Ana, la nodriza, La sombra de la madre, La harpía, Los hermanos, Llega Hemón, Creón, Antígona y Los desconocidos. La tumba de Antígona está estructurada como una obra dramatúrgica; empero, consideramos que la propuesta literaria que comporta, más que para ser llevada a escena, es para ser leída. Como hemos mencionado en líneas anteriores, la doncella yace dentro de su tumba y diversas entidades, o memorias convocadas, se turnan para visitarla. De este modo, la aparición de cada visitante supone el intercambio de preguntas y respuestas, durante los cuales destaca, in crescendo, la comprensión mostrada por la joven cuya talla espiritual y conciencia no cesan de aumentar. Esta pieza literaria se despliega con innegable y profunda intención filosófica.

Advirtamos el señalamiento esclarecedor que el padre de la doncella de Tebas le hace durante su visita: "Edipo: Oh Antígona, tengo yo que decirte dónde estás, cuando es tan claro; todo esto es tan claro. Estás en el lugar donde se nace del todo. Todos venimos a ti por eso." (p. 234). El problema de la humanidad y sus sinsentidos, solo han podido ser comprendidos desde la absoluta condena: únicamente a partir de su muerte social, la Antígona de María Zambrano vislumbra las inconsistencias que aprisionan la condición humana de la cual siguen siendo cautivas las entidades, personajes que la visitan, mientras, a su vez, ella se libera progresiva e ineludiblemente.

Antígona pronuncia: "No, tumba mía, no voy a golpearte. No voy a estrellar contra ti mi cabeza. No me arrojaré sobre ti como si fueras tú la culpable. Una cuna eres; un nido. Mi casa. Y sé que te abrirás." (ZAMBRANO, 1986. p. 225). Recordemos que, para María Zambrano, la filosofía pregunta y la poesía responde. Esta obra literaria fue escrita por una autora que en su vida luchó contra la opresión de la sociedad sexista y segregadora, logrando imponer su sólida vocación intelectual. Más adelante, la doncella declara:

Seguiré sola con toda la vida, como si hubiera de nacer; como si estuviese naciendo en esta tumba. $\mathrm{O}$ acaso ¿no nací dentro de ella, y todo me ha sucedido dentro de la tumba que me tenía prisionera? Dentro siempre de la familia: padre, hermana, hermano y hermano, siempre, siempre así. (ZAMBRANO, 1986, p. 226).

La corta vida de Antígona ha sido de absoluta opresión, estando, de un modo u otro, prisionera desde su nacimiento. A partir de la reelaboración de María Zambrano, argumentamos que la tumba de su existencia podría organizarse a partir de las siguientes etapas / funciones. Primero, como mujer-hija, confinada al espacio físico y psicológico del hogar de su familia y a la voluntad y expectativas de su madre y su padre, los constantes desacuerdos entre sus hermanos y las crecientes tensiones entre todos ellos. Más tarde, como joven virgen prometida en matrimonio, sometida a la vigilancia de su prometido y de la sociedad tebana. En tercer lugar, como ciudadana-súbdita, condenada y reducida a la soberbia de Creón, que es, al mismo tiempo, su tío y futuro suegro, juez superior y rey de Tebas. Vemos el siguiente fragmento del diálogo entre Creón y la doncella de Tebas:

ANTÍGONA: ¿también tú tampoco tú puedes pasarte sin venir a esta tumba?

CREÓN: No temas, Antígona ¿No ves la puerta abierta?

ANTÍGONA: Será para ti. Yo no volveré a pasar nunca por esa puerta. 
CREÓN Como siempre, te adelantas: antes a mi justicia, ahora a mi clemencia. Vengo a sacarte de esta tumba. La

muerte de mi hijo, precipitado como tú, me impidió sacarte de aquí a tiempo para que celebrarais vuestras nupcias. Yo quería sólo darte una lección.

ANTÍGONA: Ah, ¿No era la ley, que yo bajara aquí para desvivirme a solas como un reptil entre las piedras?

CREÓN: Ya: empiezas, Antígona, haces que se me olvide lo que venía a decirte. Sí; se me va de la cabeza. Pero mi decisión es mi decisión y la mantengo por encima de tus palabras. La puerta está ahí, mírala, abierta. Vamos Antígona. Ve delante de mí. Sube tú antes que yo, sube tú primero.

ANTÍGONA: He subido ya, aunque me encuentras aquí, tan abajo. Siempre estuvimos todos nosotros debajo de ti. Pues eres de esos que para estar arriba necesitan echar a los demás a lo más bajo, bajo tierra si no se dejan. Confórmate con eso, Creón. ¿Qué otra cosa quieres? (ZAMBRANO, 1986. p.255)

En el personaje de Creón convergen todas las instancias de subyugación de Antígona. Es bajo la identidad de este personaje que se configuran las forma el poder y la raíz de la máxima tensión ante la cual, la identidad femenina de Antígona es subyugada y anulada en el mito reelaborado por Sófocles. La Antígona de María Zambrano, yaciendo al interior de la tumba se enfrenta a Creón, quien deseoso de seguir ejerciendo su dominio sobre ella y habiéndola reducido a la cueva sepulcral, le ordena regresar al reino "de los hombres", bajo el Sol del imperante mundo social. La joven mujer se niega, ante el asombro de Creonte, que sale de la caverna con su soberbia e incomprensión intactos. Oliveira y Caser, apuntan:

En la obra de Zambrano se abordan cuestiones variadas como el mito, el amor, la guerra, la sororidad, pero el estado de soledad que inunda la esencia de Antígona, resultante del exilio a que es forzada a vivir en virtud de la tragedia que se abate sobre su familia, es el eje principal del drama, cuyos elementos la autora toma de Sófocles y desarrolla basada en la filosofía, en lenguaje fuertemente poético (OLIVEIRA y CASER, 2019, p. 5)

La determinación de la doncella sabia supera su sumisión y se impone como un ultimátum cuyo eco, en la obra de la autora española, prefigura un modelo de preguntas incesantes cuyas respuestas aparecen a los ojos de las lectoras y los lectores con indudable intención filosófica y profundidad poética. La vida a la que esta Antígona se acerca en cada página es la conciencia, la luz que se enciende con la comprensión de su propia condición y la imposibilidad de una perspectiva completa del mundo sin la libertad o el amor: para la sabia Antígona de María Zambrano, cuya comprensión resplandece, vivir no es más que permitirse el tiempo de buscar la verdad.

\section{ELECTRA: ENTRE EL DESAFÍO DE LA VOLUNTAD Y EL SUEÑO}

La tragedia de Sófocles, fue creada entre el 418 y el 410 a.C, y presenta a la joven Electra, hija de Agamenón, rey de Micenas y Clitemnestra; sus hermanos son Orestes, Crisótemis e Ifigenia. Esta última es sacrificada en procura de buenos augurios para el 
viaje que emprenderían el padre y su flota a la Guerra de Troya de la cual tardan diez ańos en regresar. Clitemnestra guarda dentro de sí rencor y odio hacia Agamenón por el sacrificio de la hija para ganar el favor de Ares, dios de la guerra. Dada la tardanza del monarca, la reina de Micenas tiene un amante, Egisto con quien urde la muerte del rey. Al volver del conflicto, Agamenón resulta asesinado por su esposa en complicidad con su amante. Electra, quien ha vivido en condiciones deplorables mientras ha durado el viaje de guerra de su padre, sufre indeciblemente con la muerte de éste y aparece atormentada y llena de indignación e ira hacia su madre y Egisto. Pide ayuda a su hermana Crisótemis para llevar a cabo la venganza, pero la hermana se niega. Electra termina asociándose con su hermano y asesinando a su madre; Orestes, por su parte, mata a Egisto.

La pieza de Edith Ibarra, al igual que la tragedia de Sófocles, ha sido concebida para realizarse ante el público: pretende también, de este modo, dialogar con las y los asistentes y el complejo contexto contemporáneo a cuyo ruedo se arrojan los personajes. En Otra Electra ${ }^{3}$ (2011), hallamos pues a la joven protagonista entrando junto con su madre al apartamento de ésta, quien ha sido sometida a una cirugía ocular por lo cual se encuentra vendada y requiere sus cuidados. Los personajes se sitúan en la actualidad, y por todo espacio, la sala, las habitaciones y la cocina del piso materno. Ambas mujeres entablan un diálogo que introduce a las y los lectores (espectadores de la puesta en escena) en la compleja relación madre-hija.

La Electra de Ibarra, lidia, en pleno siglo XXI, con su madre convaleciente, prodigándole cuidados, debatiéndose perennemente entre el afecto y la culpa y yendo de la desesperación al hastío y del reclamo a la conciliación. La mexicana, es también, una Electra distinta, que habita, aparentemente, en la superficie de lo cotidiano, no obstante, en su atormentada vida interior yace en una compleja batalla que pasa por el cuestionamiento de los roles femeninos impuestos por el entramado familiar y social, y en sus ansias por rebelarse e imponer su voluntad, busca comprender y superar las sugestivas pesadillas que la asedian. Expresa a su vez, la necesidad de hallar algunos significados y rehuir del temor de las situaciones que tienen lugar durante sus sueños aterradores y repetitivos. La pieza se divide en doce partes o cuadros, como sigue:

\author{
Cuadro I La presentación. \\ Cuadro II ¿Y el ratón? \\ Cuadro III El sueño de todos los días \\ Cuadro IV Otra Electra \\ Cuadro V Al otro día, un café \\ Cuadro VI Las llamadas
}

3 Corren los primeros días del mes de abril de 2021. Al momento de escribir este artículo, la puesta en escena de la obra Otra Electra de la autora mexicana Edith Ibarra está llevándose a cabo, todos los domingos, vía transmisión en línea -en tiempo real-, por el portal web Teatro La Capilla. La boletería está disponible para la compra del público en el lapso comprendido entre el pasado 14 de febrero y el 18 de abril del presente año. Parece oportuno destacar que, dada la actual coyuntura pandémica, adquirimos los boletos en línea y disfrutamos de la puesta en escena de la obra vía Zoom; una función en vivo que el equipo de producción y el reparto hicieron posible de una manera más que impecable. Teatro La Capilla: https://www.teatrolacapilla.com/otra-electra/ 


\author{
Cuadro VII Comamos pizza \\ Cuadro VIII Nuevamente la pesadilla \\ Cuadro IX Luchando contra la pesadilla \\ Cuadro X El mismo infierno de siempre \\ Cuadro XI Morando en la pesadilla \\ Cuadro XII El regreso
}

Una de las claves de las cuales nos asimos para abordar y comentar la pieza de Edith Ibarra, reposa en el título, que, para muchos, podría ser una obviedad en el establecimiento de la vinculación con la tragedia sofocleana. El nombre de Electra refulge invitándonos a asumir un nexo aparentemente claro. Sin embargo, la palabra "Otra" encabeza dicho título, confiriéndole un cariz interesante y sugerente, a nuestro modo de ver, sobre lo que el público pudiera hallar e interpretar.

La protagonista de la dramaturga azteca, aparentemente, no es la Electra reelaborada por Sófocles hace cerca de dos mil quinientos años. En la pieza, nuestra Electra contemporánea interpela a su madre, con la cual discute, a propósito de su nombre, en un intercambio lleno de sarcasmo. La Madre evocando, se centra en la impresión, la sensación que el nombre elegido para su hija le produce y justifica así, por toda razón, el habérselo puesto. La joven, por su parte, manifiesta el rechazo a su nombre, pues rehúsa "ser como ella", como aquella Electra. Ante la irritación de la joven, la Madre aclara para ella, para las lectoras y lectores y para el público, que, sin duda, la hija no es aquella Electra, sino "otra".

Electra: ¿Por qué me pusiste Electra?

La Madre: Me gusta la fuerza de tu nombre.

Electra: ¿Cuál fuerza?

La Madre: Yo siento que cuando digo Electra llamo a una guerrera.

Electra: ¿Leíste la obra?

La Madre: Me gusta el nombre, las historias no me interesan.

Electra: Siempre le inventas cosas a la gente.

La Madre: ¿No te gusta tu nombre?

Electra: No...Electra...no quiero ser como ella.

La Madre: Tú eres otra, otra Electra.

Electra: Te falta una pantufla.

La Madre: Sí. No la pude encontrar.

Electra: Espérame. Te la voy a traer.

(IBARRA, 2011, p. 22)

Esa aparente ambigüedad en la identidad de "esta" Electra contemporánea introducida por Ibarra desde el título, nos lleva, necesariamente a destacar la alusión brillante y profunda que la autora azteca propone al público destinatario e interlocutor de su pieza teatral, desde la consideración de las categorías de inconsciente colectivo 
y arquetipo que el trabajo del célebre psiquiatra suizo Carl Jung aportara durante la primera mitad del siglo XX:

Uma camada mais ou menos superficial do inconsciente é indubitavelmente pessoal. Nós a denominamos inconsciente pessoal. Este porém repousa sobre uma camada mais profunda, que já năo tem sua origem em experiências ou aquisiçôes pessoais, sendo inata. Esta camada mais profunda é o que chamamos inconsciente coletivo. Eu optei pelo termo "coletivo" pelo fato de o inconsciente năo ser de natureza individual, mas universal; isto é, contrariamente à psique pessoal ele possui conteúdos e modos de comportamento, os quais săo 'cum grano salis' os mesmos em toda parte e em todos os indivíduos. Em outras palavras, săo idênticos em todos os seres humanos, constituindo portanto um substrato psíquico comum de natureza psíquica suprapessoal que existe em cada indivíduo. (JUNG, 2000. p.15)

El inconsciente colectivo junguiano, en tanto ese "substrato psíquico" que abarca, entre otros elementos, "formas de comportamiento", constituye, a nuestro criterio, un asidero fundamental con el cual dialoga el texto dramático de Edith Ibarra en cuenta del producto arquetipal constituido en el mito de Electra, en la reelaboración de Sófocles y la suya propia. Esta Electra se llama como la griega y aunque sabe que no es ella... teme hacer lo mismo que aquella hizo. Esta Electra ha sido marcada por el nombre de la joven micénica e intuye, en dicho nombre, una suerte de oscuro destino en ciernes, una amenaza.

El sentido del corto diálogo entre Madre e hija a propósito del nombre, intercambio tirante y en apariencia superficial, enerva a nuestra Electra (la mexicana) y abre una hendidura tan breve como profunda en la carga significativa que sugiere varias posibilidades de sentido. La primera, es que esta Electra no es la del mito, la reelaborada en la tragedia, sino una Electra diferente; la segunda, que es una Electra más, llamada así entre otras tantas posibles Electras. La tercera alternativa abierta de sentido, es que nuestra Electra mexicana, si bien, no es la griega, personifica una nueva atormentada versión que yace increpando a su madre.

Para finalizar este apartado, constatamos dos personajes referenciales cuyos significados son substanciales y determinantes en la existencia de "esta" Electra y la dinámica de la difícil relación que experimenta con su madre. En primer lugar, el padre de nuestra protagonista, quien, en el presente de la obra, ya ha muerto. El personaje de la Madre, lejos de asesinarlo como en la tragedia sofocleana, trata, cada vez con menos éxito, de arruinar su imagen, al traspasar los que considera rasgos negativos del esposo fallecido del cual reniega, a su hija Electra. Con lo cual, tiene lugar un sostenido intento de someterla por medio de la manipulación y agredirla, atribuyéndole injustas semejanzas con el progenitor.

\section{Electra toma la escoba y el trapeador}

Electra: Voy por el desayuno. No voy a escuchar el comercial de siempre.

La Madre: Ya no te acuerdas de cómo me trataba.

Electra: Tú se lo permitiste.

La Madre: Para ti es muy fácil echarme la culpa de todo. Si lo aguanté fue para que 
no sufrieras el tener padres divorciados.

Electra: Sí, era mejor sufrir con unos padres que se peleaban a la menor provocación.

La Madre: ¿Y qué esperabas, que no hiciera nada? Yo no soy como las indias de su pueblo que viven sometidas a la voluntad del marido.

Electra: ¿Por qué seguiste con él si te trataba tan mal?

La Madre: Tú solo criticas, no quieres darte cuenta de los sacrificios que hice por ustedes.

Electra: Ya empezó la telenovela. Voy por el desayuno.

La Madre: Eres igualita a él. Empiezan a hablar y cuando ya no saben qué decir, se van.

Electra: Antes me sentía muy mal cuando me comparabas con él. Pensaba que parecerme a mi papá era la cosa más horrible que me podía pasar. Pero ya no lo vivo así. Dime otra cosa si me quieres ofender.

Electra espera. La Madre sigue en silencio. Sale.

(IBARRA, 2011, p. 31)

Horacio, hermano de Electra, constituye el segundo personaje referencial que entra en la trama de la obra solo en los diálogos y acciones entre la Madre y la protagonista. Ansiosa de las atenciones de su hijo siempre ausente, la Madre excusa constantemente la actitud indiferente de aquél ante sí misma y ante Electra. Esta última resuelve llamarlo por teléfono y en un diálogo en el cual las y los lectores (y el público) sólo escuchan la voz de Electra, la joven reclama y señala de forma directa e inequívoca las consecuencias de la indiferencia de su hermano, que como hijo varón es dispensado socialmente de los cuidados para con su madre, mientras que, en su carácter de hija y mujer, Electra recibe todo el peso de la responsabilidad y ve consumir su tiempo y su vida enteros, a disposición de las demandas maternas; instituidos ambos comportamientos -el de Horacio y el de Electra- en las estructuras patriarcales de sometimiento de las mujeres ante el poder y el posicionamiento masculino.

Electra: Bueno... ¿Horacio? Soy yo, Electra. ¡Maldito hombre!... ¿Qué haces? ¿Yo? Peleando con mi mamá, ya sabes. Mi deporte favorito...No, no puedo dejar de hacerlo. No soy como tú que le sigues la corriente...¿Cómo me voy a callar si se la pasa provocándome? Oye, ¿cuándo vas a venir?...Sí, ya sé que siempre estás muy ocupado pero ella te necesita...No, tú no vengas a pelear....además contigo ella es diferente. Aunque sea ven a darle las buenas noches...Íbamos a desayunar pero a mí ya se me quitó el hambre...¿Por qué no te quedas unos días con ella?...Un fin de semana...Antes de Navidad...¿Por qué tengo que cuidarla sólo yo?...¿Por qué tengo que estar con ella? (IBARRA, 2011, p.33)

La obra teatral de Edith Ibarra constituye una interpretación de perspectiva psicológica, cuyo tratamiento y reelaboración de la identidad femenina de la figura de Electra, cuestiona las configuraciones del patriarcado, el sometimiento y las desigualdades que deben enfrentar las mujeres. De este modo, durante ese proceso dialógico que protagoniza Electra con La Madre en la vigilia, y consigo misma en la urdimbre de sus sueños, ocurre la restitución de su derecho a increpar a su entorno, el desafío de sortear las complejidades de la realidad y conservar su propia voz. 


\section{A MODO DE CIERRE: ANTÍGONA Y ELECTRA RESTITUIDAS}

Con el respaldo de las notas de Jesús F. Polo Arrondo, en la traducción de Sófocles concluimos que las protagonistas de las tragedias Antígona y Electra, en las versiones del gran autor griego, son mujeres cuyos rasgos identitarios femeninos resultan interpretaciones de la visión epocal del presente de esas obras y en función de las cuales sus mitos fueron allí tematizados. Guardan en común rasgos como el entrañable amor y el respeto por los miembros de sus familias y, en particular, por sus respectivas figuras paternas. Ambas jóvenes se encuentran oprimidas por las configuraciones del patriarcado y, en sus condiciones de mujeres/hijas, los elementos que resaltan en sus perfiles en el desarrollo de las piezas, a menudo, son el sometimiento absoluto, zozobra, inquietud, sumisión, satisfacción de las exigencias demandadas por su entorno, incertidumbre ante la propia suerte, rabia, indignación.

Antígona y Electra no solo llegan hasta nuestros días precedidas por la fatalidad y el horror de "sus destinos", sino habiendo sido anuladas y acorraladas, literalmente, desde el entramado patriarcal que ponía sus jóvenes vidas bajo el absoluto sometimiento reinante en el ámbito familiar y social. Las quejas y los lamentos resultan las formas de expresión más frecuentes y permitidas para las protagonistas de las tragedias sofocleanas. Solo en la resolución de sus respectivos conflictos, la tebana y la micénica tuvieron oportunidad de demostrar sus criterios para juzgar y sus capacidades para emprender y llevar a cabo aquello que finalmente se hubieren propuesto, pese a que ello las condujera, inevitablemente, hacia sus finales sombríos. Dicha inevitabilidad parece resultar concomitante con sus identidades desde la masculina perspectiva de Sófocles y el contexto de la Grecia antigua al que responden y con el cual dialogan las tragedias referidas.

En contraste, La tumba de Antígona y Otra Electra tienen en común una circunstancia fundamental: nos presentan las identidades de las jóvenes míticas desde la interpretación femenina. Ambas protagonistas se encuentran tan atormentadas como aferradas a sus respectivos presentes e intentando encontrar el sentido de su existencia. Antígona, siendo increpada por sus entidades visitantes; y Electra, asediada por su madre y por las experiencias durante sus inquietantes sueños. Sin embargo, las voces de ambas se ven restituidas por cuanto fustigan e interpelan sus correspondientes contextos, desligándose de sus resoluciones más oscuras.

La Antígona de Zambrano, lejos de suicidarse, se abre a un diálogo estético-filosófico durante el cual alcanza su comprensión y la de su contexto y legitima su identidad femenina recién descubierta frente a las demandas del mundo social que la ha perseguido hasta el interior mismo de su caverna sepultura. La Electra de Ibarra, lejos de asesinar a su progenitora, se encuentra brindándole cuidados. Lidia con su entorno opresor durante los diálogos fustigantes que entabla con su madre, al increpar directamente a su hermano y mientras duerme, al afrontar sus propios deseos reprimidos.

Las versiones de las escritoras espańola y mexicana se distancian de los finales/ resoluciones lapidarios y definitivos; antes bien, brindan a las y los lectores la posibilidad de reflexionar sobre las posturas, derrotas y hallazgos que Antígona y Electra despliegan en los decursos de sus recreaciones, cuestionando y denunciando el trato desigual, la opresión y la violencia instituidos en la sociedad en virtud del sometimiento de las mujeres. 
Las jóvenes retratadas por Sófocles hace dos mil quinientos años en sendas tragedias, cuyos anhelos, angustias y destinos eran compartidos por las y los espectadores, sin embargo, terminaban siendo abatidas por las decisiones finales que situaron en la palestra de la cultura occidental sus famosos mitemas: el entierro del amado hermano y el posterior suicidio y el asesinato de la madre, respectivamente. Tales decisiones daban, a la vez, por terminada, cualquier otra posibilidad de diálogo de las jóvenes mujeres con el mundo social. María Zambrano y Edith Ibarra nos han brindado en sus obras un par de interpretaciones que, a nuestro criterio, restituyen las voces de las primigenias ciudadanas; la de Tebas y la de Micenas (ahora mexicana). Lejos de encontrarse como víctimas/presas de batallas perdidas o conflictos irresolubles, han trascendido sus trágicos finales y se encuentran encarando las complejidades de sus mundos sociales y la sostenida opresión de sus identidades por parte de aquellos; sus voces surgen revelándolas en medio del sendero de sus correspondientes desafíos. 


\section{REFERENCIAS}

AMAYA, Z. R. El mito de la belleza. Una exploración al inconsciente colectivo del venezolano. Revista Estudios Culturales. Vol. 7, Nro. 13. Enero-Junio. pp. 95-109. 2014. Disponível: http://servicio.bc.uc.edu.ve/multidisciplinarias/estudios_culturales. Acceso em: 05 abr. 2021.

GARCÍA GUAL, C. Diccionario de mitos. Madrid: Siglo XXI de España, Editores S.A., 2003. GENETTE, G. Palimpsestos. La literatura en segundo grado. Traduçăo de Celia Fernández Prieto. Madrid: Taurus, 1983.

IBARRA, E. Otra Electra. México: Dirección General de Publicaciones del Consejo Nacional para la Cultura y las Artes, 2011.

JUNG, CG. Os arquétipos e o inconsciente coletivo. Traduçăo de Maria Luíza Appy, Dora Mariana R. Ferreira da Silva. Petrópolis, RJ: Vozes, 2000.

OLIVEIRA, E. A. V.; CASER, M. M. La tumba de Antígona, de María Zambrano, el mito recreado. Revista Historia de las Mujeres. Lima, Año XX, No. 184, febrero - marzo 2019. Disponível:https://www.cemhal.org/anteriores/2019_2020/05EsterAbreu.pdf. Acceso em: 01 de mar. 2021.

RINALDI, D. Procedimientos intertextuales en Fedray otras griegas de Ximena Escalante. Revista Nova Tellus. Vol. 26, Nro. 2. UNAM, México. 2000. pp.293-321. Disponível: https://revistas-filologicas.unam.mx/nouatellus/index.php/nt/article/view/284. Acceso em: 20 fev. 2021.

SÓFOCLES. Antígona. Introducción, traducción y notas de Jesús F. Polo Arrondo. Madrid: Ediciones Rialp, S. A., 2014.

SÓFOCLES. Electra. Em: Antígona, Edipo Rey, Electra. Madrid, Guadarrama, pp.191286, 1969.

ZAMBRANO, M. La Tumba de Antígona. Barcelona: Editorial Anthropos, 1986 [1968]. 